\title{
Publisher Correction: Prevalence of monoclonal gammopathy of undetermined significance (MGUS) at HIV diagnosis in individuals 18-40 years old: a possible HIV indicator condition
}

Michele Bibas (D), Silvia Pittalis @D, Nicoletta Orchi, Gabriella De Carli, Chiara Agrati, Enrico Girardi, Andrea Antinori,

Vincenzo Puro and Giuseppe Ippolito

Correction to: Blood Cancer Journal https://doi.org/10.1038/s41408-021-00489-1

published online 16 May 2021

In the original article, an error occurred in the names, all family names are in place of the first names, even if the Orcid connection is right.

The correct author names are:
Michele Bibas, Silvia Pittalis, Nicoletta Orchi, Gabriella De Carli, Chiara Agrati, Enrico Girardi, Andrea Antinori, Vincenzo Puro \& Giuseppe Ippolito

The original article has been updated.

Published online: 02 June 2021

(c) (i) Open Access This article is licensed under a Creative Commons Attribution 4.0 International License, which permits use, sharing, adaptation, distribution and reproduction in any medium or format, as long as you give appropriate credit to the original author(s) and the source, provide a link to the Creative Commons license, and indicate if changes were made. The images or other third party material in this article are included in the article's Creative Commons license, unless indicated otherwise in a credit line to the material. If material is not included in the article's Creative Commons license and your intended use is not permitted by statutory regulation or exceeds the permitted use, you will need to obtain permission directly from the copyright holder. To view a copy of this license, visit http://creativecommons.org/licenses/by/4.0/. 